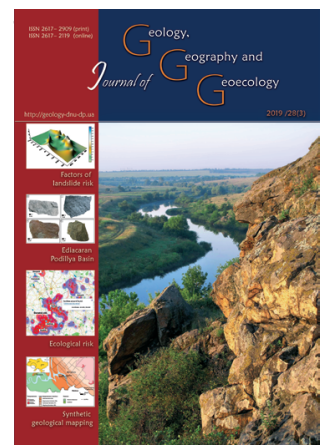

Journal of Geology.

\title{
Peculiarities of geological and thermobaric conditions for the gas hydrate deposits occurence in the Black Sea and the prospects for their development
}

\author{
V. Bondarenko, K. Sai, M. Petlovanyi \\ Underground Mining Department,Dnipro University of Technology,Dnipro,Ukraine,petlyovany@ukr.net
}

Received: 15.02 .2019

Received in revised form: 03.03.2019

Accepted: 22.04.2019

Abstract. The actuality has been revealed of the necessity to attract the gas hydrate deposits of the Black Sea into industrial development as an alternative to traditional gas fields. This should be preceded by the identification and synthesis of geological and thermobaric peculiarities of their existence. It was noted that the gas hydrates formation occurs under certain thermobaric conditions, with the availability of a gas hydrate-forming agent, which is capable of hydrate formation, as well as a sufficient amount of water necessary to start the crystallization process. The gas hydrate accumulation typically does not occur in free space - in sea water, but in the massif of the sea bed rocks. The important role in the process of natural gas hydrates formation is assigned to thermobaric parameters, as well as to the properties and features of the geological environment, in which, actually, the process of hydrate formation and further hydrate accumulation occurs. It was noted that the source of formation and accumulation of the Black Sea gas hydrates is mainly catagenetic (deep) gas, but diagenetic gas also takes part in the process of gas hydrate deposits formation. The main component of natural gas hydrate deposits is methane and its homologs - ethane, propane, isobutane. The analysis has been made of geological and geophysical data and literature materials devoted to the study of the offshore area and the bottom of the Black Sea, as well as to the identification of gas hydrate deposits. It was established that in the offshore area the gas hydrate deposits with a heterogeneous structure dominate, that is, which comprises a certain proportion of aluminosilicate inclusions. It was noted that the Black Sea bottom sediments, beginning with the depths of 500-600 m, are gassy with methane, and a large sea part is favourable for hydrate formation at temperatures of $+8 \ldots+9^{\circ} \mathrm{C}$ and pressures from 7 to $20 \mathrm{MPa}$ at different depths. The characteristics of gas hydrate deposits are provided, as well as requirements and aspects with regard to their industrialization and development. It is recommended to use the method of thermal influence on gas hydrate deposits, since, from an ecological point of view, it is the safest method which does not require additional water resources for its implementation, because water intake is carried out directly from the upper sea layers. A new classification of gas hydrate deposits with a heterogeneous structure has been developed, which is based on the content of rocks inclusions in gas hydrate, the classification feature of which is the amount of heat spent on the dissociation process.

Keywords: gas hydrate deposit, development, geological peculiarities, thermobaric conditions, dissociation, methane

\section{Особливості геологічних та термобаричних умов існування газогідратних покладів Чор- ного моря, перспективи їх розробки}

\author{
В. Бондаренко, К. Сай, М. Петльований
}

\section{Національний технічний університет “Дніпровська політехніка”, Дніпро, Украӥна petlyovany@ukr.net}

\begin{abstract}
Анотація. Розкрита актуальність необхідності залучення у промислове освоєння газогідратних родовищ Чорного моря як альтернативи традиційним газовим родовищам, чому повинно передувати виявлення та узагальнення геологічних і термобаричних особливостей їх існування. Відзначено, що формування газових гідратів відбувається за умов правильної комбінації температури і тиску, а також наявності газу-гідратоутворювача, здатного до гідратоутворення, та достатньої кількості води, необхідної для початку процесу кристалізації. Накопичення газового гідрату, як правило, відбувається не у вільному просторі - морській воді, а в масиві донних порід. Важлива роль у процесі формування природних газогідратів відведена термобаричним параметрам, а також властивостям і особливостям геологічного середовища, у якому, власне, й відбувається процес гідратоутворення та подальшого гідратонакопичення. Відзначено, що джерелом утворення та накопичення чорноморських газогідратів є переважно катагенетичний (глибинний) газ, але у процесі формування газогідратних покладів приймає участь
\end{abstract}


також і діагенетичний газ. Основним компонентом природних газогідратних покладів є метан та його гомологи - етан, пропан, ізобутан. Проведено аналіз геолого-геофізичних даних і літературних матеріалів, присвячених вивченню акваторії та дна Чорного моря, а також виявленню покладів газових гідратів. Встановлено, що в акваторії моря переважають газогідратні поклади неоднорідної структури, тобто такі, що містять певну частку алюмосилікатних включень. Відмічено, що чорноморські донні відкладення, починаючи з глибин $500-600$ м, загазовані метаном, а значна частина моря сприятлива для гідратоутворення при температурах $+8 \ldots+9^{\circ} \mathrm{C}$ і тиску від 7 до 20 МПа на різних глибинах. Висвітлені характеристики газогідратних покладів, вимоги та аспекти щодо їх промислового освоєння й розробки. Рекомендовано застосування методу теплового впливу на газогідратний поклад, оскільки з екологічної точки зору він $є$ найбільш безпечним, не потребує залучення додаткових водних ресурсів для його реалізації, оскільки забір води здійснюється безпосередньо з верхніх однорідних шарів моря. Розроблено нову класифікацію газогідратних покладів неоднорідної структури, що базується на вмісті породних включень у газогідраті, класифікаційною ознакою якої є кількість тепла, що витрачається для протікання процесу дисоціації.

Ключові слова: газогідратний поклад, розробка, геологічні особливості, термобаричні умови, дисоціаиія, метан

Introduction. Every year in Ukraine there is a tendency to increase the fossil fuel consumption, the reduction of the reserves of coal, gas and oil in the traditional fields, fluctuation and constant increase in prices for imported hydrocarbon crude. Therefore, the search for and development of alternative energy sources is becoming increasingly important. In modern conditions it is necessary to modernize the structure of the oil-gas and coal state sectors, the changeover to new mining technologies (Falshtynskyi, Lozynskyi, Saik, Dychkovskyi, \& Tabachenko, 2016; Falshtynskyi, Saik, Lozynskyi, Dychkovskyi, \& Petlovanyi, 2018), as well as to use the nanotechnologybased solutions for the utilization of coalmine methane and its application as an energy source (Bondarenko, Kovalevs'ka, \& Ganushevych, 2014; Hanushevych \& Srivastava, 2017). By improving the development mechanisms of the energy segment of the country, it is possible to obtain additional energy products, in particular gas from coal deposits (Lozynskyi, Saik, Petlovanyi, Sai, \& Malanchuk, 2018) and coal itself, which today is still an important energy source, despite the difficulties in the process of its extraction (Petlovanyi, Lozynskyi, Saik, \& Sai, 2018). The development and introduction of gas production technologies by means of underground gasification of coal in complex mining and geological conditions is of special attention (Lozynskyi et al., 2018).

It is promising to obtain gas from gas hydrate deposits along with methane from coal deposits, shale gas and the gas from compressed sandstones. At the moment, the advanced countries of the world - India, Canada, China, Germany, Norway, USA, Japan, etc. - are engaged in the development of technologies for gas production from gas hydrates deposits. For Ukraine, the gas hydrate deposits of the Black Sea are of considerable interest, since gas reserves concentrated in the Ukrainian part $\left(20-25\right.$ trillion $\left.\mathrm{m}^{3}\right)$ exceed by several times the existing gas reserves of traditional fields. This will provide Ukraine with the energy source for several centuries, taking into account all the necessary needs of both the industrial state sector and the population. Moreover, the role of methane, possessed by our country, in the coming years may become decisive in the gas market redistribution.

A significant problem in the fuel and energy sector of Ukraine today is the lack of hydrocarbon crude, in particular natural gas, as well as the absence of a clearly developed strategy for exporting this energy source from abroad. Most Ukrainian deposits, both coal and gas, are in the final stage of development (Piwniak, Bondarenko, Salli, Pavlenko, \& Dychkovskiy, 2007). Thus, for today, $85 \%$ of prospected oil reserves and $77 \%$ of gas reserves have been extracted. Ukraine belongs to a number of countries suffering from power shortages, that is, which satisfy the need for energy resources at the expense of domestic production less than by $50 \%$ (in gas by $23-25 \%$, in oil by $12-15 \%$ ). Our country is among the top five countries in terms of the use of imported natural gas per capita (Annual report..., 2016; Annual report..., 2017).

The conditions of natural gas production in Ukraine are constantly becoming more complicated due to the gradual depletion of the highest quality reserves and the growing share of lower quality reserves with a lower extraction potential and higher cost. For today, the gas production in the country is characterized by the following features: a high degree of the primary reserves depletion of major large fields; low rates of new reserves prospecting (the replacement rate of gas produced by new reserves over the past 20 years is below $100 \%$ ); low quality of new reserves (reserves are divided between a large number of small fields and a significant part of these reserves are difficult to access); an increase in the depth of drilling in both existing and new fields (the average depth of drilling for gas production is about $3500 \mathrm{~m}$, the maximum depth already exceeds $6000 \mathrm{~m}$ ).

Given the above, it is possible to predict the next trend in the development of gas producing Ukrainian companies in the near future:

- development of new onshore fields, including small ( $1-5$ billion $\mathrm{m}^{3}$ of gas reserves) and sufficiently 
small (up to 1 billion $\mathrm{m}^{3}$ of gas reserves);

- development of the coastal Black and Azov Sea beds and river deltas;

- application of efficient drilling technologies at depths of $6000-7000 \mathrm{~m}$ );

- introduction of new technologies for gas production from alternative energy sources, which, first of all, include the Black Sea gas hydrate deposits.

The problem of energy supply can be fundamentally solved by involving the development of natural gas hydrate deposits of the Black Sea that are promising for use, since the gas reserves which are concentrated in the Ukrainian part by several times higher than the existing gas reserves of traditional fields. However, for this it is necessary to identify and summarize the geological and thermobaric peculiarities of the gas hydrate deposits occurrence, as well as to study the thermodynamic conditions of their formation for the further development of production directions and technologies.

Purpose of research - identification of geological and thermobaric peculiarities of formation and existence of the Black Sea gas hydrate deposits in order to improve the development of the directions and technologies of their production on the basis of systematization and generalization of the data of literary sources, information resources, own developments; development of gas hydrate deposits classification according to the rock inclusions content and the amount of thermal energy consumed on the gas hydrates dissociation.

Methods of research. To achieve the purpose set, an integrated approach was used in the work that includes processing and summarizing the literature and patent sources devoted to the study of peculiarities and thermobaric properties of gas hydrates, methods of the gas hydrate deposits development. The geological, geophysical, and climatic data on the conditions of hydrate accumulation and the formation of gas hydrate deposits in the Black Sea offshore area, as well as the distribution maps of the most promising areas of gas hydrate content were studied in detail. To generalize the gas hydrate deposits, their classification has been made according to the rock inclusions content and the energy spent for the dissociation of a deposit.

Research results. The peculiarities of gas hydrates formation and accumulation in natural conditions.

The gas hydrates are solid ice-like crystalline compounds formed by water and natural gas molecules, in which water molecules are bonded to each other by hydrogen bonds and form scaffolds with large cavities inside (Gas hydrate, 2007). The ability of water to form gas hydrates is conditioned by the presence of hydrogen bonds in it. The chemical bonds are not formed between the molecules of gas and water. The guest-molecules (hydrate-forming agents) placed in lattice cells, stabilize the system, because in itself the crystalline host-lattice (water molecules) is thermodynamically metastable, when it is not filled with a minimal amount of gas molecules (Kvenvolden, 1994; Carroll, 2014).

The gas hydrates are formed under condition of low temperatures and high pressure (Fig. 1), provided

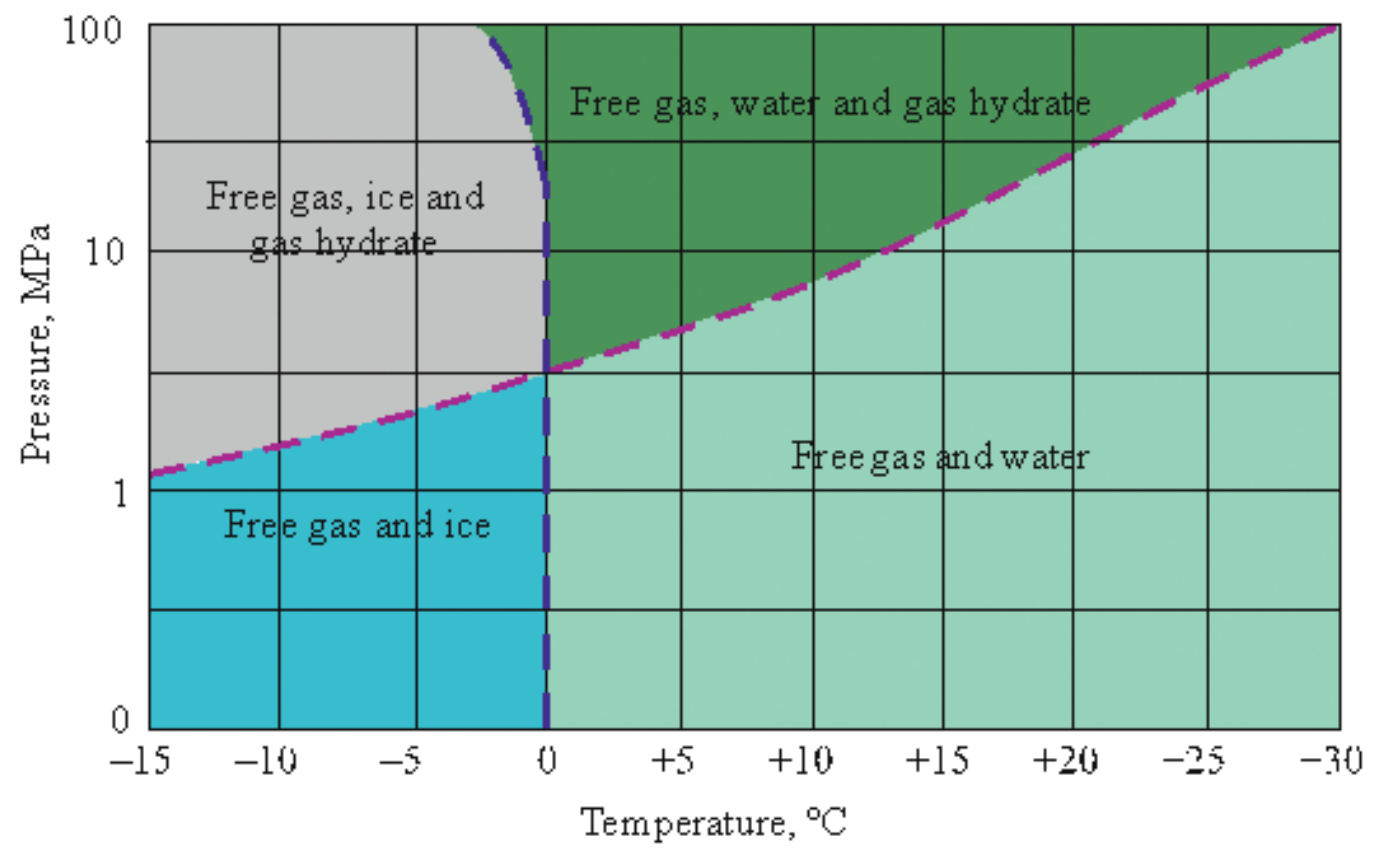

Fig. 1. Phase diagram of the gas hydrates existence: ----- the boundary line of "water - ice" phases; ----- the boundary line of "gas hydrate - free gas and water" phases 
that there is a sufficient amount of hydrate-forming gas and water. The properties inherent in gas hydrates are unique. One volume of water, when changing to the hydrate state, binds up to 200 volumes of methane. Moreover, its specific volume increases by $26 \%$ (when freezing, the specific volume of water increases by $9 \%) .1 \mathrm{~m}^{3}$ of methane hydrate at a pressure of $2.63 \mathrm{MPa}$ and a temperature of $0^{\circ} \mathrm{C}$ contains $164 \mathrm{~m}^{3}$ of gas. Therewith, the fraction of gas accounts for $0.2 \mathrm{~m}^{3}$, for water $-0.8 \mathrm{~m}^{3}$ (Makogon, 1997; Boswell, 2009).

During the periods of gas hydrates research, it has been found that such components of natural gas as $\mathrm{CH}_{4}, \mathrm{C}_{2} \mathrm{H}_{6}, \mathrm{C}_{3} \mathrm{H}_{8}, \mathrm{C}_{4} \mathrm{H}_{10}, \mathrm{CO}_{2}, \mathrm{~N}_{2}, \mathrm{H}_{2} \mathrm{~S}$ etc., form both individual and mixed hydrates (their composition includes several gases). However, it was not established the possibility of the gas hydrates formation of such gases as $\mathrm{H}_{2}$, $\mathrm{He}$ and $\mathrm{Ne}$ (Bondarenko, Kovalevska, Astafiev, \& Malova, 2018).

The gas hydrates formation occurs under the following conditions:

- appropriate temperature and pressure: as a rule, the formation of hydrates is caused by a rather low temperature and rather high pressure;

- gas hydrate-forming agent must be available: methane, ethane, propane, carbon dioxide or any other gas capable of hydrate formation;

- sufficient amount of water is required to start the hydrate formation process.

The gas hydrate accumulation, as a rule, does not occur in free space - in sea water, but in the massif of the sea bed rocks. The important role in the process of natural gas hydrates formation is assigned to the parameters of pressure and temperature, as well as to the properties and features of the medium, in which, actually, the process of hydrate formation and further hydrate accumulation occurs.

The thickness of gas hydrate strata ranges from hundreds of meters (when the deposits are located at a shall depth (less than $500 \mathrm{~m}$ )) to $1 \mathrm{~km}$ or more (when the deposits are located at great depths). A constant companion and source of natural gas hydrates formation can be free gas, located under the gas hydrate deposit. In some areas of bottom sediments, its concentration is so high that it begins to penetrate into the free spaces between the rock particles. As the gas hydrates are accumulated in sedimentary rocks, these rocks become impermeable. An enclosed space is formed, capable of self-compacting, in which the gas is accumulated which tends to rise upwards. The more free gas penetrates into the hydrate formation zone, the stronger the gas hydrate deposit becomes. After complete saturation of the gas hydrate stratum, the free gas can be accumulated already under it.

The lower line of occurring the gas hydrate deposits is determined by the geothermal gradient in the bottom rocks. About $99 \%$ of gas hydrate reserves are located in the offshore areas of the seas and oceans. In the onshore conditions, there is also the necessary thermobaric combination of pressure and temperature sufficient for the formation of natural gas hydrates and its homologs. It should be noted that in the continental rocks there is less water and less free space in which crystalline hydrates are formed (Makogon, 2010a).

It has been established that gas hydrate accumulations in mine rocks exist in the form of the following cryohydrate structures: massive (in sandy soils); porphyry (in sandy-loam soils); lenticularschlieren (in clay soils).

The gas hydrates may be a cement or simply fill in the voids without cementing the sediment grains. Strengthening sedimentary rocks occurs due to the presence of hydrates in them, performing the role of cement. Also, the gas hydrates can exist in the pore space, without having a noticeable influence on the stiffness and strength of sedimentary rocks. The gas hydrates formation in the seas in the conditions of bottom rocks suggests the filling of the existing voids not with water, but with a solid gas hydrate skeleton (Pedchenko \& Pedchenko, 2017).

To assess the gas hydrates energy potential, it is important to determine the possible variants of their location in the sedimentary mass and to determine the properties of hydrate-bearing strata. Having analysed the existing data on the findings of gas hydrates in the Earth's interior, a conclusion can be made that gas hydrates exist in rocks in the form of small inclusions, beams, veinlets, and massive strata.

The gas hydrates formation in sedimentary deposits occurs according to two different variants of hydrate accumulation:

- the first, when gas hydrates are formed and accumulated at contacts of the rock particles, which leads to cementation of the sedimentary deposits skeleton;

- the second, when the gas hydrates formation occurs directly in the cavities and pores. According to this variant, it is obvious that hydrates have almost no influence on the connection of rock particles, which leads to the sedimentary mass compaction.

Geological and thermobaric conditions of hydrate formation, availability of gas hydrates in the Black Sea. The issues of deposits development, related directly to the consideration of geological structure, are constantly actual for all types of min- 
erals (Petlovanyi, 2016; Maksymova \& Kostrytska, 2018; Petlovanyi, Lozynskyi, Zubko, Saik, \& Sai, 2019). The existing technologies for identifying the gas hydrate deposits are based on using the properties of hydrates and hydrate-saturated rocks. The most widely used method is standard and high-frequency seismology, according to data of which, the position of the lower boundary of hydrate-saturated rocks is determined with an availability of free gas under the hydrate-saturated strata - Bottom Simulation Reflector (BSR) boundary (Thakur \& Rajput, 2010).

The study of the conditions for gas hydrates formation, their stable existence and properties in natural environment makes possible to confidently predict their occurrence in different onshore areas, in the World Ocean, and in particular in the Black Sea. The Black Sea offshore area is characterized by the occurrence of gas hydrate deposits, the thickness of which, according to geologists and seismic survey results, reaches at an average of $1000 \mathrm{~m}$ from the sea bed surface. The Ukrainian part of the sea has methane gas resources, which can be extracted from the gas hydrate deposits located directly opposite the Crimean Peninsula, about $20-25$ trillion $\mathrm{m}$. The total projected gas resources throughout the Black Sea are at least 100 trillion $\mathrm{m}^{3}$, based on the results of drilling and the studied cores analysis $(1988$ - 1989) (Korsakov, Byakov, \& Stupak, 1989; Gas hydrates..., 1990).

The Black Sea is one of the largest and deepest seas. The average sea depth is $1300 \mathrm{~m}$. The maximum depth, according to different sources, based on the echo-sounding survey data, is in the range of $2210-2258 \mathrm{~m}$. The river streams inflowing into the sea have a limited runoff through the narrow Bosphorus Strait, with $32 \mathrm{~m}$ in depth and about $750 \mathrm{~m}$ in width. The mixing of water is determined only by winds to shall depths and low-powered seepages located at depths up to $700 \mathrm{~m}$.

The bottom temperatures are around $+9^{\circ} \mathrm{C}$. Plankton can exist only in the upper 200-meter layer of water, which is mixed, and contains dissolved oxygen. At great depths, the water is saturated with hydrogen sulfide, where only anaerobic bacteria that generate hydrogen sulfide can exist. The vertical water circulation is practically absent. There is also no migration of dissolved gases, generated in the upper "living" water layer, into the deep hydrogen sulfide layer.

The Black Sea uniqueness is as follows:

- it is the world's largest meromictic reservoir, in which almost stagnant water column has been accumulated and that does not circulate;

- it is the relatively young "closed" sea (pool isolation affected the water saturation with hydrogen sulfide, as well as the generation and dynamics of hydrocarbons);

- absence of life at depths greater than $200 \mathrm{~m}$, except sulphur bacteria;

- giant methane reservoir.

The modern Black Sea basin is a part of the large Alpine orogenic belt. It is the north-eastern segment of the Mediterranean mobile belt. In the north, these two depressions border on the southern edge of the East European Platform, in the east they border on the zone of the Taman dome structures, which are the western extension of the Caucasian orogen, in the south - the Anatolian fold structures, in the west - the structures of the Mysia Plate and the Dobruji mountain structures. The north-western part of the Black Sea offshore is a tectonic depression (trough) of the Northern Black Sea region, which arose in the late Maykop time between Dobruji in the west and the Crimean Peninsula in the east. In the south, the depression is opened toward the large Black Sea depression, and in the north it is deeply embedded within the East European Platform (Nikishin et al., 2015; Vespremeanu \& Golumbeanu, 2017).

In the offshore area of the Black Sea, there are three main geomorphological elements at the bottom: the shelf, the continental slope, and the deepwater depression. The Black Sea shelf is the coastal part of the sea bed to depths of $90-110 \mathrm{~m}$. The geological shelf structures are a continuation of the onshore structures. The shelf, or continental shelf, occupies $25 \%$ of the sea offshore area. The continental slope corresponds to a narrow zone of steep bend of the sea bed from the outer shelf to depths of $1830 \mathrm{~m}$ and occupies about $40 \%$ of the offshore area. The deep-sea depression of the Black Sea (about 35\% of the offshore area) is a flat accumulative plain that extends from the west to the east in the oval form and is slightly inclined to the south. Its bottom is almost flat, it is characterized by a relief with small protuberances, the inclination angles vary in the range of 0 to $1^{\circ}$. There were not found the large forms of submarine relief according to the echometry surveys data. The depths everywhere are over $2000 \mathrm{~m}$.

The analysis of thermobaric conditions within the deepwater area of the Black Sea Depression gives every reason to assert that the available temperature and pressure parameters at the sea depths of $500-750 \mathrm{~m}$ are optimal for the gas hydrate deposits formation under such conditions (97/01843 Thermodynamic conditions..., 1997; Demirbas, 2009; Shnyukov, 2013). The lower boundary of these deposits occurrence is $400-500 \mathrm{~m}$ below the sea bed 


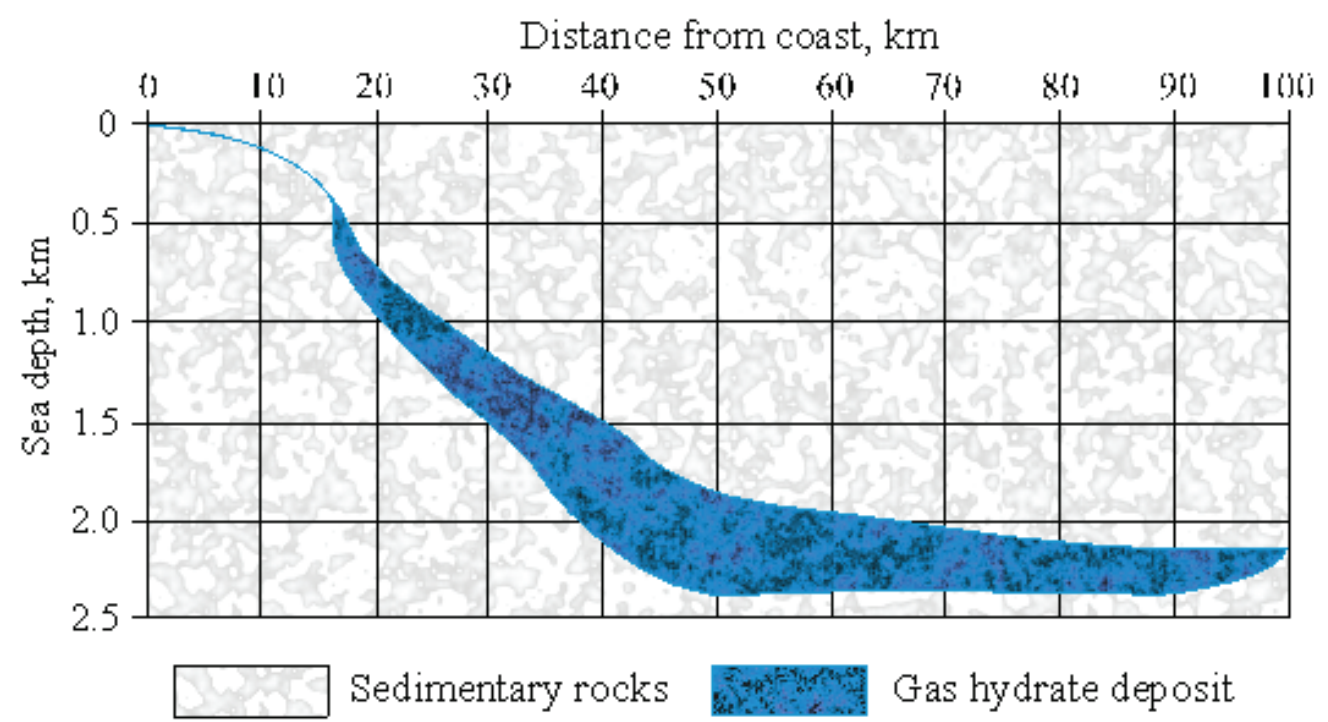

Fig. 2. The zone of gas hydrates formation in the Black Sea (Makogon, 2010b)

and depends on the sea depth. In Fig. 2, there is a rock stratum of the gas hydrate deposits occurrence, which is located to the south of the Crimean Peninsula.

During the research process aimed at studying the heat flux distribution in the Black Sea depression, A.D. Duchkov and S.A. Kazantsev discovered a wide and lengthy zone of reduced (almost twice) heat flux, which is stretched across the entire offshore area from west to east, and the similar anomaly in the northern Black Sea part, opposite the Kerch Strait (Duchkov \& Kazantsev, 1988). With account of these data, the thickness of hydrate formation zone for these areas can reach $1000-1200 \mathrm{~m}$, which is confirmed by the results of seismic operations by means of the common depth point method in the Western Black Sea depression. Therefore, it can be stated that the hydrate formation zone covers the entire deepwater depression and a significant part of the continental slope.

For the first time, the possibility of the natural gas hydrates availability in the bottom Black Sea sediments was expressed by A.G. Efremova and B.P. Zhizhchenko during the expeditions, when in one of the soil columns lifted from a depth of about $2000 \mathrm{~m}$ (location was not indicated), white, frost-like microcrystalline growths were found inside large voids at $6.5 \mathrm{~m}$ from the surface, which disappeared quickly when being lifted on the ship's deck. Then it was suggested a possible gas hydrate origin of the detected crystals (Efremova \& Zhizhchenko, 1974).

In 1988, the Computing Center of the Siberian Branch of the Academy of Sciences of the USSR and the All-Union Scientific Research Institute of Oceanology, the USSR Ministry of Geology, conducted a special expedition in the Black Sea aimed at identifying gas hydrates ( 21 cruise of the research vessel "Evpatoria") in the deepwater part of the Sorokin Trough. During the expedition, it was found and partially studied the accumulation of gas hydrates associated with diapir structure, located to the south of the Crimean Peninsula at water depths down to $1400-2200 \mathrm{~m}$. The most effective manifestation was noted in clay breccia at a depth of about $2000 \mathrm{~m}$ in a column interval of $70 \mathrm{~cm}$, where a monomineral hydrate sample with $8 \mathrm{~cm}$ in length and $12 \mathrm{~cm}$ in diameter was obtained, which corresponded to the internal diameter of the pipe. In other samples, thin $(3-5 \mathrm{~mm})$ but lengthy veinlets were noted. The total hydrate content was about $10 \%$, the rest was rocks. In the gas hydrate composition methane prevailed (97-98\%), ethane content was $0.02-0.4 \%$, carbon dioxide $-0.5-0.9 \%$, hydrogen sulfide $-0.25 \%$ (Ginsburg, Kremlev, \& Grigor'yev, 1989).

The first exploratory seismic surveys in the Black Sea, performed by the SEVRMORGEO of the Russian Academy of Sciences in 1988 discovered 5 gas hydrate areas. The most promising area is located $20 \mathrm{~km}$ to south of Yalta. This is a large area where search and exploration of gas hydrate deposits should be focused. Other promising areas are located in the waters of Russia, Turkey and Georgia. In 1989, gas hydrates were discovered within one of the zones of diapir-like folds' development and local disturbances in the central part of the sea, $90 \mathrm{~km}$ south of Saryich Cape.

During the cruise of the research vessel "Gelendzhik", under the ANAXIPROBE/TTR6 program in 1996, gas hydrates were also discovered in the Sorokin Trough and the central part of the Black Sea. In the course of work, three different types of gas hydrate structures were described: layers of massive 
gas hydrates (as pure hydrated ice, so with a small proportion of rocks inclusions); gas hydrates massive pieces with irregular shape, randomly distributed in the mud-volcano breccia near the rock fragments; thin lenses and hydrate layers, oriented in parallel to the bedding of sediments and to the sea bed. The data obtained during the expedition allowed the authors to conclude that gas hydrates are widely distributed in the studied area and in large volumes (Ivanov, Limonov, \& Woodside, 1998).

In 2001, the studies on gas hydrates were carried out again in the Black Sea. In the course of work, gas hydrates were found in sediments in the Sorokin Trough and were the plates of $2-3 \mathrm{~mm}$ thick and more than $5 \mathrm{~cm}$ in diameter. Also, the gas hydrates have been found in sediments of the north-western Black Sea part. By their structure, they were very porous and brittle by sense of touch, up to several centimeters in size. Based on visual observations, it was possible to distinguish two types of sedimentary hydrate-forming textures. The type of texture, when gas hydrates are more or less uniformly distributed in sediments, can be attributed to porphyry or massive type. In addition, some gas hydrate samples were oriented along the sedimentary stratification of the enclosing sediments.

An important issue that determines the approach to the study of patterns of gas hydrates formation in the subsoil, is the question of the sources of hydrocarbon gases and how they enter into the zone of hydrate formation. Some researchers consider that the genetic factor is no less important in the formation of gas hydrate deposits than the thermodynamic one. The classification is based on the concept of the main geological models of natural gas hydrate formation - cryogenic, eustatic, sedimentary, filterogenic and diagenetic. For the Black Sea Depression conditions, the most probable are sedimentary, filterogenic and diagenetic types of gas hydrate deposits.

One of the sources can be gaseous products of biochemical conversion of organic matter (methane, hydrogen sulfide, carbon dioxide, etc.). Therewith, some scientists admit the presence of gases inflow that saturate the pore water to levels sufficient for the crystalline hydrates formation. When gas-saturated deposits being submerged within the hydrate formation zone, primary gas hydrate deposits are formed, which fill the sea bed along with bottom rocks.

A.O. Trofimuk believes that gas hydrates can be accumulated in the stratal waters under the conditions of their considerable undersaturation with gas and at available appropriate thermobaric conditions. In this case, it is an important fact that the presence of litho- logical rocks is not necessary for the deposit formation, since the layer which contains the gas hydrates, becomes almost impermeable for gaseous hydrocarbons when filling $65-70 \%$ voids volume with hydrates. This finding is very important for assessing the potential of the Black Sea Depression, since the possibility of formation in the bottom sediments ( $300-500 \mathrm{~m}$ below the bottom) a layer impermeable to gases, allows to consider a wide range of objects, and increases significantly the potential of the entire sedimentary cover (Trofimuk, Cherskiy, Makagon, \& Tsarev, 1973).

Another important source of hydrocarbon gases is migration flows of catagenetic natural gases entering the hydrate formation zone through tectonic (fractures, crushing zones) and lithological channels from the main oil-gas formation zone. An important factor that initiates the migration processes, is the neotectonic activity of the earth's crust, which is characteristic of the Black Sea region.

The thickness of the hydrate formation zone essentially depends on the value of the temperature gradient and heat flux. In zones with low heat flux $\left(25-30 \mathrm{~mW} / \mathrm{m}^{2}\right)$, the thickness of hydrate formation stratum can be $350-400 \mathrm{~m}$, with an increase in heat flux up to $40 \mathrm{~mW} / \mathrm{m}^{2}$, it decreases to $200-250 \mathrm{~m}$, and at heat flux values of $60 \mathrm{~mW} / \mathrm{m}^{2}$ and more - it is reduced to tens of meters. In zones with abnormally high heat fluxes $\left(80-100 \mathrm{~mW} / \mathrm{m}^{2}\right)$, the gas hydrate stratum is most likely absent (Starostenko, Shnyukov, Kobolev, Rusakov, \& Kutas, 2008).

The Black Sea bottom sediments, starting at depths of $500-600 \mathrm{~m}$, are gassy with methane. The powerful gas emissions in the form of numerous seepages, fountains, mud volcanoes were recorded almost along the entire Black Sea perimeter. Currently, about 4000 gas flames have been discovered, localized on the periphery in the Black Sea offshore, in particular, in the north-west of the Black Sea, the Bulgarian, Kerch-Taman shelves, along the coast of the Caucasus and on the continental slope and shelf of Turkey.

As mentioned above, the source for the Black Sea gas hydrates formation and accumulation is predominantly catagenetic (deep) gas, but diagenetic methane is also involved in the formation of gas hydrate deposits. The main component of natural gas hydrate deposits is methane and its homologs - ethane, propane, isobutane. Also the gas, which is released after the decomposition of gas hydrates, contains steam-like gases - pentane and hexane. They are not included into the gas hydrates structure, but are probably adsorbed by the surface. The proportion of methane is $93.3-98.9 \%$, the proportion of its homo- 
logs is $1.1-6.7 \%$.

Some gas hydrates contain $100 \%$ of methane. The performed studies have shown the presence not only of hydrocarbon gases in the gas hydrate deposits, but also of nitrogen, carbon dioxide and hydrogen sulphide. However, their proportion is extremely low (Makogon, 2010a).

The gas hydrates have also been found at depths of $2000 \mathrm{~m}$, which indicates the deep origin of the gas contained in gas hydrate deposits. This made possible to identify two main types of gas hydrate deposits in the Black Sea deepwater areas for O.S. Gorshkov and his colleagues (Gorshkov, Meysner, \& Tugolesov, 1992):

- gas hydrates which are connected with migration gases that go through tectonic disturbances and mud volcanoes; formation zones are localized in the Black Sea mainly in the quaternary deposits, which reach a thickness of $1-3 \mathrm{~km}$, in the Sorokin Trough occasionally even in neogene. The criterion for the availability of gas hydrates in sediments on seismic profiles is a specific imaging, which displays the bottom configuration.

According to the regional seismic profiles by a grid of $25 \times 25 \mathrm{~km}$, made by the SEVRMORGEO association, a significant distribution of gas hydrates deposits within the deepwater Black Sea part has been set, and a map of prospects for gas content in the hydrate formation zone has been constructed (Fig. 3) (Korsakov, Byakov, \& Stupak, 1989; Bondarenko, Ganushevych, Sai, \& Tyshchenko, 2011).

According to this map, the most promising are the central, northeastern and northern parts of the Black Sea, where a special attention should be focused on

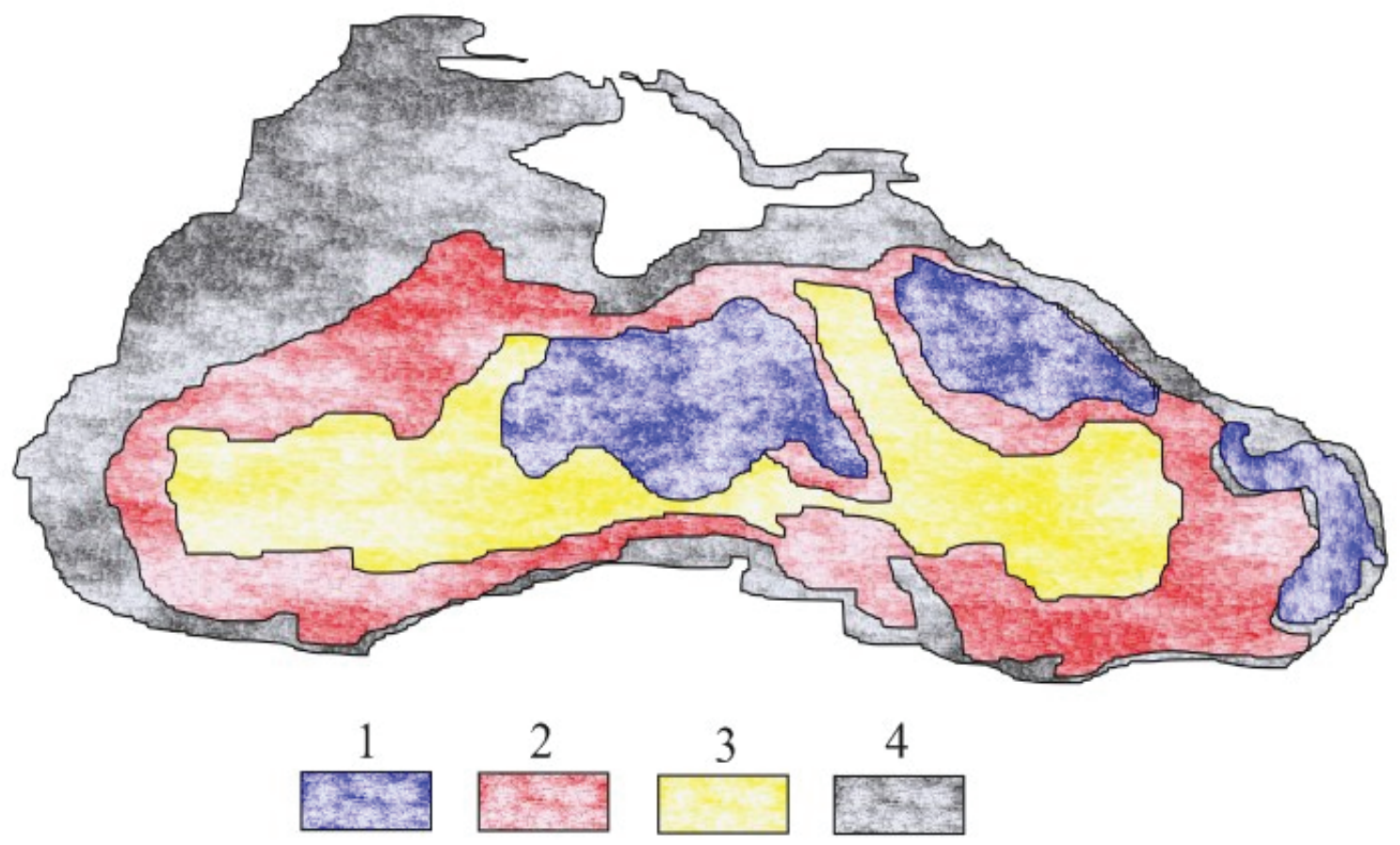

Fig. 3. The map of prospects for gas content in the hydrate formation zones of the Black Sea Depression: 1 - highly promising zones of hydrate formation; 2 - promising zones of hydrate formation; 3 - little promising zones of hydrate formation; 4 - unpromising zones of hydrate formation

- gas hydrates of river fans.

The predicting assessment of the gas content potential in the Black Sea subsoil is most clearly expressed in the work of O.D. Korsakov, O.Yu. Byakov, S.M. Stupak (Korsakov, Byakov, \& Stupak, 1989). For hydrate formation, the situation is favorable practically in the whole deepwater Black Sea Depression. The regional geophysical studies of these authors have provided a spatial pattern of the natural gas hydrates distribution in the Black Sea. The hydrate the technologies development of gas extraction out of the gas hydrate deposits (Bondarenko, Maksymova, Ganushevych, \& Sai, 2013; Bondarenko, Sai, Prokopenko, \& Zhuravlov, 2018).

Given the above, and based on the results of their own research (Bondarenko, Svietkina, \& Sai, 2018), the authors have made a conclusion that in the Black Sea offshore, the gas hydrate deposits predominate of heterogeneous structure, that is comprising a certain proportion of aluminosilicate inclusions. This proves 
the fact that the limous bottom compounds practically are aluminosilicates of different composition with an admixture of metal oxides - iron, magnesium, titanium, calcium, etc. Although in the natural state, clay minerals have low adsorption and catalytic activity, they can be activated through ion exchange, hence, this makes it possible to regulate their porous structure. Such activation leads to a sudden growth of the surface and mesopores volume, which is conditioned by the formation of amorphous silica, which has pores that are available not only for water molecules, but also for hydrocarbons.

The Black Sea waters, as a rule, are not prone to freezing. The average water temperature in the sea does not fall below $+7 \ldots+8^{\circ} \mathrm{C}$, in winter it rises from -0.5 to $0^{\circ} \mathrm{C}$ in the coastal areas of the northwestern convection, and in other areas is formed mainly by the transfer of cold water by currents;

- constant halocline - a layer of maximum salt content increase with a depth, which is located in the contact zone of the upper (Black Sea) and deep (Marmara Sea) water masses;

- deep layer - from $200 \mathrm{~m}$ to the bottom, where there are no seasonal changes in hydrological characteristics, and their spatial distribution is sufficiently uniform.

Aspects of criteria choice for the gas hydrate deposits development. The choice and substantiation of the technological schemes and the appropriate rational parameters of the gas hydrate deposits development should include the implementation of several stages and be carried out for the conditions

Table 1. The average values of the Black Sea water temperature by horizons, ${ }^{\circ} \mathrm{C}$

\begin{tabular}{|c|c|c|c|c|c|c|c|c|c|c|c|c|}
\hline 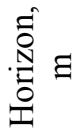 & 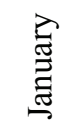 & 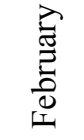 & 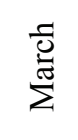 & $\overline{\bar{z}}$ & 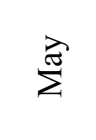 & $\stackrel{\Xi}{\Xi}$ & $\stackrel{\lambda}{\Xi}$ & 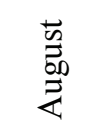 & 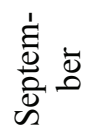 & $\begin{array}{l}\dot{\overline{0}} \\
\stackrel{0}{0} \\
\stackrel{0}{0} \\
0\end{array}$ & 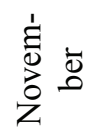 & 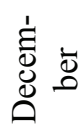 \\
\hline 0 & +7.7 & +7.2 & +6.8 & +9.2 & +14.1 & +19.8 & +22.8 & +23.8 & +20.8 & +18.7 & +11.7 & +9.5 \\
\hline 10 & +7.7 & +7.1 & +6.8 & +9.0 & +12.8 & +18.5 & +21.8 & +23.6 & +20.7 & +18.6 & +11.8 & +9.6 \\
\hline 20 & +7.7 & +7.0 & +6.7 & +8.4 & +10.2 & +11.9 & +12.2 & +13.6 & +19.2 & +17.9 & +11.6 & +9.6 \\
\hline 30 & +7.7 & +7.0 & +6.7 & +7.7 & +7.9 & +7.8 & +8.5 & +9.0 & +9.1 & +12.0 & +10.4 & +9.2 \\
\hline 50 & +7.6 & +7.4 & +7.3 & +7.6 & +7.4 & +7.3 & +7.4 & +7.6 & +7.2 & +8.0 & +7.6 & +7.8 \\
\hline 100 & +8.3 & +8.3 & +8.3 & +8.3 & +8.3 & +8.3 & +8.3 & +8.3 & +8.3 & +8.3 & +8.3 & +8.3 \\
\hline 200 & +8.5 & +8.5 & +8.5 & +8.5 & +8.5 & +8.5 & +8.5 & +8.5 & +8.5 & +8.5 & +8.5 & +8.5 \\
\hline 500 & +8.9 & +8.9 & +8.9 & +8.9 & +8.9 & +8.9 & +8.9 & +8.9 & +8.9 & +8.9 & +8.9 & +8.9 \\
\hline 700 & +9.0 & +9.0 & +9.0 & +9.0 & +9.0 & +9.0 & +9.0 & +9.0 & +9.0 & +9.0 & +9.0 & +9.0 \\
\hline 1000 & +9.0 & +9.0 & +9.0 & +9.0 & +9.0 & +9.0 & +9.0 & +9.0 & +9.0 & +9.0 & +9.0 & +9.0 \\
\hline 1500 & +9.0 & +9.0 & +9.0 & +9.0 & +9.0 & +9.0 & +9.0 & +9.0 & +9.0 & +9.0 & +9.0 & +9.0 \\
\hline
\end{tabular}

part, to $+7 \ldots+8^{\circ} \mathrm{C}-$ in the central, and $+9 \ldots+10^{\circ} \mathrm{C}-$ in the southeastern part of the sea. In summer, the water surface layer is warmed up to $+23 \ldots+26^{\circ} \mathrm{C}$. The average water temperature by horizons is shown in Table 1.

Beginning with the horizons of $150-200 \mathrm{~m}$, the salt content and temperature of water slowly increase to the bottom caused by the influence of more salt and warm waters flowing into the deep layers. In the vertical hydrological structure of the Black Sea waters, the following main components are distinguished:

- a homogeneous upper layer and seasonal (summer) thermocline layer, mainly related to the process of windy mixing and the summer cycle of heat flux through the sea surface;

- a cold intermediate layer with a minimum temperature at a depth, which in the northwest and northeast of the sea occurs as a result of autumn-winter of each specific field (Bondarenko, Maksymova, \& Koval, 2013; Maksymova, 2018). The gas hydrate deposits of high priority and that suitable for development can be chosen according to the principle proposed in the work (Petlovanyi \& Medianyk, 2018). Taking into account the peculiarities of gas production from gas hydrates and guided by the Rules for the development of oil and gas fields, as well as by the Law of Ukraine "On Oil and Gas", it is obvious that the gas hydrate field should be characterized as follows (Zakon Ukrainy..., 2018):

1. According to the geological structure complexity of the productive gas hydrate horizons:

- fields with a complex geological structure, which have a variable nature of productive horizons - lithological composition, reservoir characteristics, etc.; 
- fields with a simple geological structure, productive deposits of which are characterized by relative continuity of lithological composition, reservoir characteristics and productive horizons over the entire deposit area.

2. By the number of developed deposits:

- single-layered, when there is only one deposit or all deposits are combined into one object of development;

- multi-layered, when several objects are allocated for development.

3. By thermobaric parameters.

4. According to the degree of deposit saturation with gas hydrates, depending on the rocks porosity, the hydrate density, the thermodynamic characteristics and the range of development depths.

5. According to the designed maximum possible operating specific productivity index of future boreholes: decreased, low, medium and high specific productivity indeces.

6. By the value of the initial strata pressure: low, medium and high pressure.

For gas hydrate field, which is accepted for development, the following steps should be performed:

- a preliminary detailed exploration of the place of deposit occurrence, assessment of gas reserves, which are in the form of gas hydrates;

- determining the distinct boundaries of the field, density and porosity of host rocks;

- performance of full-scaled tests and studies in several boreholes in order to obtain the main distinguishing deposit characteristics;

- identification of structural and geometric peculiarities of the deposit structure;

- establishment of the basic characteristics of productive strata: thickness, porosity, permeability, gas recovery factor, thermal conductivity coefficient and thermal diffusivity of host rocks.

Designing the development of a selected gas hydrate field provides for a preliminary core sampling from productive horizons in boreholes planned by the exploration project. The purpose of continuous or selective withdrawal of cores is to study the totality of the physical and chemical properties of productive deposits and the inclusions contained in them.

A complete performance of industrial geophysical research in all exploration boreholes, including the establishment of azimuth and curvature of the wellbore, is an integral component before the beginning of the gas hydrate fields development. In specially prepared boreholes, it is necessary to determine the geothermic gradient value for each selected exploration field area. Types and scope of geological and industrial research in the drilling of boreholes are established and approved by the Program of Exploration and Commercial-Test Production of the field.

The methods for gas production and classification of gas hydrate deposits according to the content of rocks inclusion and energy consumption during their dissociation. The technologies for the gas hydrate fields development and the recovery of methane gas from them are connected with the physical and chemical properties of these clathrate compounds, and based on the dissociation, by which the gas hydrates are dissociated into gas and water (Bondarenko, Ganushevych, \& Sai, 2012). To release the gas contained in hydrates, the equilibrium parameters of their stable existence can be shifted. At present, there are three main methods of gas production from gas hydrates (Processes for methane..., 2010; Rogers, 2015):

- thermal treatment method based on deposit heating;

- depressive method which is in reducing the pressure in the gas hydrate;

- substitution method or adding chemicals that are catalyst agents for the dissociation process of gas hydrate deposit.

Table 2 shows the existing subtypes of the main methods for gas extraction from gas hydrate deposits.

Table 2. Methods for the gas hydrate deposits development and the natural gas extraction from them

\begin{tabular}{|l|l|}
\hline \multicolumn{1}{|c|}{ Dissociation method } & \multicolumn{1}{c|}{ Subtypes of the method } \\
\hline \multirow{3}{*}{ Thermal treatment method } & $\begin{array}{l}\text { Method of heating with the use of injection of heat-transfer } \\
\text { medium }\end{array}$ \\
\cline { 2 - 3 } Depressive influence method & \begin{tabular}{l} 
Hot water circulation method \\
\cline { 2 - 3 } \\
steam, heated gas or liquid
\end{tabular} \\
\hline & $\begin{array}{l}\text { Method of depressurization by reducing the pressure around the } \\
\text { borehole }\end{array}$ \\
\cline { 2 - 3 } & $\begin{array}{l}\text { The method of reducing the water or free gas pressure on gas } \\
\text { hydrate after their partial pumping out }\end{array}$ \\
\hline
\end{tabular}


The thermal treatment method for gas hydrate deposits development is based on the supply of heat inside the hydrate crystalline structure to increase its temperature, which accelerates the dissociation process of crystalline hydrates. This method is suitable for the productive deposits development that have a high degree of hydrate saturation. But precisely this deposits are widely spread in the Black Sea offshore. The thermal treatment method is the safest from an environmental point of view. It does not require additional water resources for its implementation, since water intake is carried out directly from the homogeneous upper sea layers.

The temperature values of the Black Sea water by horizons, starting from clay $100 \mathrm{~m}$, does not fall below $+8^{\circ} \mathrm{C}$ (Table 1), and in summer the average temperature of the seasonal thermocline fluctuates at the level of $+20^{\circ} \mathrm{C}$, which is an additional advantage and reduces the heat consumption for heating when applying the thermal treatment method of deposit devel- a form of pure hydrate stratum, and, more often, with rock aluminosilicate inclusions, which makes the structure of the deposit heterogeneous. Thus, the efficiency of the decomposition process of gas hydrate deposits with a variable proportion of aluminosilicate inclusions depends on the amount of thermal energy consumed to produce $1000 \mathrm{~m}^{3}$ of gas (Bondarenko \& Sai, 2018). These calculations, performed by the authors in the process of research, made it possible to determine the volume of decomposition zones of heterogeneous gas hydrate deposits and the output of methane gas from the proportion of rocks inclusions.

With account of previous own developments and peculiarities of hydrate accumulation in the Black Sea sediments, the authors have developed a classification of gas hydrate deposits, which is based on the content of rocks inclusions in these deposits. The classification is based on energy consumption in the gas hydrate deposits development to produce $1000 \mathrm{~m}^{3}$ of methane gas. Thus, it is proposed to divide gas hydrate depos-

Table 3. Classification of gas hydrate deposits by energy consumption

\begin{tabular}{|c|c|c|c|}
\hline Class & Naming & $\begin{array}{c}\text { Proportion of rocks inclu- } \\
\text { sions }(\eta), \%\end{array}$ & $\begin{array}{c}\text { Amount of thermal energy } \\
\text { to produce } 1000 \mathrm{~m}^{3} \text { of } \\
\text { methane gas }\end{array}$ \\
\hline I & Almost homogeneous & $\leq 15$ & $\leq 3007.25$ \\
\hline II & Heterogeneous & $\leq 30$ & $\leq 3269.23$ \\
\hline III & Much heterogeneous & $\leq 45$ & $\leq 3549.14$ \\
\hline IV & Considerable heterogeneous & $\leq 60$ & $\leq 4764.42$ \\
\hline
\end{tabular}

opment. Also, the thermal influence method, in contrast to the depressive one, excludes the possibility of hydrates technogenic formation in the bottom-hole zone, which, in turn, could require the introduction of inhibitors to eliminate hydrate blocks in the wellbore.

To substantiate the parameters of the development method of gas hydrate fields, it is advisable to systematize and group the fields due to the diversity of their geological, morphological and thermodynamic properties in order to determine the limiting boundaries of the rational use of the thermal influence method or the choice of another, most optimal method.

The generalized data on the conditions for gas hydrates formation and existence, which are based on the existing results of the analysis of drilled borehole cores, give reason to the authors to conclude that gas hydrates are contained in the Black Sea bottom sediments at an approppriate temperature and pressure parameters corresponding to the conditions of stable existence of gas hydrate deposits, not only in its into 4 classes depending on the proportion of rocks inclusions in the gas hydrate massif (Table 3 ).

I heterogeneity class. It is assumed that this type of gas hydrate deposits contains up to $15 \%$ of inclusions, but they will not influence significantly on the conditions of development. Such deposits are considered to be almost homogeneous, since the number of inclusions does not exceed a certain limit, after which they cannot be considered as structure-forming inclusions of gas hydrate. In this case, the gas hydrate itself becomes the main rock-forming element and exists as a homogeneous gas hydrate structure.

II heterogeneity class. This type of gas hydrate deposits is most common in nature, and contains in its composition from 16 to $30 \%$ of rocks inclusions. It is characterized by intense gas recovery factor during the gas hydrate dissociation. The deposits are gas hydrate massifs with significant thickness (sometimes up to $400 \mathrm{~m}$ ).

III heterogeneity class. The gas recovery factor in the development of this type of gas hydrate deposits 
is slightly less than in the development of the II class deposits, since they contain from 31 to $45 \%$ of rock minerals inclusions.

IV heterogeneity class. The content of inclusions for this type of gas hydrate deposits varies from 46 to $60 \%$. It is obvious that almost half of the gas hydrate deposit contains rock particles. The gas recovery factor in the process of this class development of gas hydrate deposits will be the lowest.

Based on the above classification, the development of gas hydrate deposits of I - III classes is the most expedient, since the value of their gas recovery factor is significantly higher than that of deposits classified as IV class. Nevertheless, the production of gas from these deposits is also possible with account of the appropriate development parameters.

Conclusions. In view of the limited reserves of hydrocarbon energy sources in the Ukraine's interior, the significant dependence on import of these resources from other countries, fluctuations in market prices for society, it is extremely important to develop strategies for developing the production of alternative fuel sources. Such a type is gas hydrate deposits, in which the methane gas reserves significantly exceed the existing gas reserves of traditional fields, and this could provide Ukraine with a source of energy for several centuries, taking into account all the necessary needs of both the industrial state sector and the population. Moreover, the role of methane, possessed by our country, in the coming years may become decisive in the gas market redistribution.

The analysis has been made of geological and geophysical data and literature materials devoted to the study of the offshore area and the bottom of the Black Sea, as well as to the identification of gas hydrate deposits. It was set that the Black Sea bottom sediments, beginning with the depths of $500-600 \mathrm{~m}$, are gassy with methane, and a large sea part is favourable for hydrate formation. As a result, a productive zone of gas hydrate reserves has been formed, which are assessed by researchers at 100 trillion $\mathrm{m}^{3}$, and in the Ukrainian part $-20-25 \%$ of these reserves. It was noted that the gas hydrates formation occurs at the appropriate combination of temperature and pressure, the availability of a gas hydrate-forming agent and a sufficient amount of water necessary to start the crystallization process. The water temperature, where the hydrates formation is noted (below $500 \mathrm{~m}$ ) is $+8^{\circ} \mathrm{C}$, and the pressure at this depth is $6-8 \mathrm{MPa}$. The source of formation and accumulation of the Black Sea gas hydrates is mainly catagenetic (deep) gas, but diagenetic gas also takes part in the process of gas hydrate deposits formation. That is, there are all fa- vorable conditions in the Black Sea for the formation of a stable structure of gas hydrates with a high degree of hydrate saturation.

The accumulation of gas hydrate does not occur in free space - in sea water, but in the massif of the sea bed rocks, which indicates the heterogeneous structure of gas hydrate deposits and the neccesity to take this feature into account when calculating the amount of thermal energy for the dissociation of gas hydrate deposit. There are two variants of hydrate accumulation - at contacts of the rock particles, which leads to cementation of the sedimentary deposits skeleton, and the formation of gas hydrates in the cavities and pores.

It has been established that gas hydrate accumulations in mine rocks exist in the form of the following cryohydrate structures: massive (in sandy soils); porphyry (in sandy-loam soils); lenticularschlieren (in clay soils). The gas hydrates may be a cement or simply fill in the voids without cementing the sediment grains. The sedimentary rocks strengthening occurs due to the presence of hydrates in them, which perform the role of cement. Also, the gas hydrates can exist in the pore space, without having a noticeable influence on the stiffness and strength of sedimentary rocks. The gas hydrates formation in the seas in the conditions of bottom rocks suggests the filling of the existing voids not with water, but with a solid gas hydrate skeleton.

It was determined that under the conditions of the Black Sea basin, the gas hydrate deposits dominate of not pure, but of heterogeneous structure, that is, comprising a certain proportion of aluminosilicate inclusions. A new classification of gas hydrate deposits with a heterogeneous structure and with a different proportion of rock inclusions in gas hydrate has been developed, the classification feature of which is the amount of heat spent on the dissociation process.

It is recommended to focus on the thermal treatment method when developing the gas hydrate deposits. Its application is characterized by minimal impact on the Black Sea ecosystems. Due to the water intake from the upper homogeneous sea layers for decomposition of gas hydrate deposits (with a temperature not lower than $+8^{\circ} \mathrm{C}$, beginning with the depths of $100 \mathrm{~m}$, and in summer period the average temperature of the seasonal thermocline fluctuates at the level of $+20^{\circ} \mathrm{C}$ ), the heat spent for heating is significantly reduced, which is an additional advantage.

Acknowledgments. The presented results have been obtained in the framework of implementation of complex research work of GP-500 "Synthesis, optimization and parameterisation of innovation technologies for the development of gas-coal fields 
resources"; GP-501 "Identification of patterns of phase transformations of gas hydrates and the stressstrain state of the rock massif, as well as development of the innovation geotechnologies".

\section{References}

97/01843 Thermodynamic conditions for the presence of gas hydrates in sediments of the Black Sea. (1997). Fuel and Energy Abstracts, 38(3), 151. https://doi.org/10.1016/s0140-6701(97)87768-5

Annual report of PJSC "Naftogaz of Ukraine" for 2016. (2016). Kyiv: Naftohaz Group, 113 p.

Annual report of PJSC "Naftogaz of Ukraine" for 2017. (2017). Kyiv: Naftohaz Group, 148 p.

Bondarenko, V., Ganushevych, K., Sai, K., \& Tyshchenko, A. (2011). Development of gas hydrates in the Black sea. Technical and Geoinformational Systems in Mining: School of Underground Mining 2011, 55-59. https://doi.org/10.1201/b11586-11

Bondarenko, V., Ganushevych, K., \& Sai, K. (2012). Substantiation of technological parameters of methane extraction from the black sea gas hydrate. Materiaty Konferencyjne "Szkoła Eksploatacji Podziemnej", 20-24.

Bondarenko, V., Maksymova, E., Ganushevych, K., \& Sai, K. (2013). Gas hydrate deposits of the Black Sea's trough: currency and features of development. Materiaty Konferencyjne "Szkoła Eksploatacji Podziemnej", 66-69.

Bondarenko, V., Maksymova, E., \& Koval, O. (2013). Genetic classification of gas hydrates deposits types by geologic-structural criteria. Annual ScientificTechnical Colletion - Mining of Mineral Deposits 2013, 115-119. https://doi.org/10.1201/b16354-21

Bondarenko, V., Kovalevs'ka, I., \& Ganushevych, K. (2014). Progressive technologies of coal, coalbed methane, and ores mining. London: CRC Press, Taylor \& Francis Group. https://doi.org/10.1201/ b17547

Bondarenko, V., Kovalevska, I., Astafiev, D., \& Malova, O. (2018). Examination of phase transition of mine methane to gas hydrates and their sudden failure Percy Bridgman's effect. Solid State Phenomena, (277), 137-146. https://doi.org/10.4028/www.scientific.net/ssp. 277.137

Bondarenko, V.I., \& Sai, K.S. (2018). Process pattern of heterogeneous gas hydrate deposits dissociation. Naukovyi Visnyk Natsionalnoho Hirnychoho Universytetu, (2), 21-28. https://doi.org/10.29202/ nvngu/2018-2/4

Bondarenko, V., Sai, K., Prokopenko, K., \& Zhuravlov, D. (2018). Thermodynamic and geomechanical processes research in the development of gas hydrate deposits in the conditions of the Black Sea. Mining of Mineral Deposits, 12(2), 104-115. https:// doi.org/10.15407/mining12.02.104

Bondarenko, V., Svietkina, O., \& Sai, K. (2018). Ef- fect of mechanoactivated chemical additives on the process of gas hydrate formation. EasternEuropean Journal of Enterprise Technologies, 1/6(91), 17-26. https://doi.org/10.15587/17294061.2018.123885

Boswell, R. (2009). Is gas hydrate energy within reach? Science, 325(5943), 957-958. https://doi. org/10.1126/science. 1175074

Carroll, J. (2014). Natural gas hydrates: a guide for engineers. Oxford, United Kingdom: Elsevier, 340 p.

Demirbas, A. (2009). Methane from gas hydrates in the Black Sea. Energy Sources, Part A: Recovery, Utilization, and Environmental Effects, 32(2), 165171.https://doi.org/10.1080/15567030802463885

Duchkov, A.D., \& Kazantsev, S.A. (1988). Teplovoy potok vpadiny Chernogo morya [Thermal flow of the Black Sea depression]. Geophysical Fields of the Atlantic Ocean, 121-130 (in Russian).

Efremova, A.G., \& Zhizhchenko, B.P. (1974). Ob obnaruzhenii kristallogidratov gazov $\mathrm{v}$ sovremennykh akvatoriyakh [To the discovery of crystalline hydrates of gases in modern aquatic systems]. Reports of the USSR Academy of Sciences, 214(5), 1179-1181 (in Russian).

Falshtynskyi, V., Lozynskyi, V., Saik, P., Dychkovskyi, R., \& Tabachenko, M. (2016). Substantiating parameters of stratification cavities formation in the roof rocks during underground coal gasification. Mining of Mineral Deposits, 10(1), 16-24. https://doi. org/10.15407/mining10.01.016

Falshtynskyi, V., Saik, P., Lozynskyi, V., Dychkovskyi, R., Petlovanyi, M. (2018). Innovative aspects of underground coal gasification technology in mine conditions. Mining of Mineral Deposits, 12(2), 68-75. https://doi.org/10.15407/mining12.02.068

Gas hydrate. (2007). Hawley's condensed chemical dictionary. Hoboken, New Jersey, United States: John Wiley \& Sons. https://doi. org/10.1002/9780470114735.hawley07697

Gas Hydrates in the Black Sea basin. (1990). Deep Sea Research Part B. Oceanographic Literature Review, 37(12), 1115. https://doi.org/10.1016/ s0198-0254(06)80411-5

Ginsburg, G.D., Kremlev, A.N., \& Grigor'yev, M.N. (1989). Otkrytie fil'trogennykh gazovykh gidratov na Prikrymskom kontinental'nom podnozhii [The discovery of filterogenic gas hydrates on the Crimean continental rise]. Reports of the USSR Academy of Sciences, 309(2), 409-411 (in Russian).

Gorshkov, A.S., Meysner, L.B., \& Tugolesov, D.A. (1992). Perspektivy neftegazonosnosti Chernomorskoy glubokovodnoy vpadiny [Perspective of oil and gas content of the Black Sea deep-water depression]. Geology of the Seas and Oceans, (3), 219-220 (in Russian).

Hanushevych, K., \& Srivastava, V. (2017). Coalbed methane: places of origin, perspectives of extraction, alternative methods of transportation 
with the use of gas hydrate and nanotechnologies. Mining of Mineral Deposits, 11(3), 23-33. https:// doi.org/10.15407/mining11.03.023

Ivanov, M.K., Limonov, A.F., \& Woodside, J.M. (1998). Extensive deep fluid flux through the sea floor on the Crimean continental margin (Black Sea). Geological Society, London, Special Publications, 137(1), 195-213. https://doi.org/10.1144/gs1. sp.1998.137.01.16

Korsakov, O.D., Byakov, Y.A., \& Stupak, S.N. (1989). Gas hydrates in the Black Sea Basin. International Geology Review, 31(12), 1251-1257. https://doi. org/10.1080/00206818909465977

Kvenvolden, K.A. (1994). Natural gas hydrates occurrence and issues. Annals of the New York Academy of Sciences, (715), 232-246.

Lozynskyi, V., Saik, P., Petlovanyi, M., Sai, K., \& Malanchuk, Y. (2018). Analytical research of the stress-deformed state in the rock massif around faulting. International Journal of Engineering Research in Africa, (35), 77-88. https://doi. org/10.4028/www.scientific.net/jera.35.77

Lozynskyi, V., Saik, P., Petlovanyi, M., Sai, K., Malanchuk, Z., \& Malanchuk, Y. (2018). Substantiation into mass and heat balance for underground coal gasification in faulting zones. Inzynieria Mineralna, 19(2), 289-300. https://doi.org/10.29227/ IM-2018-02-36

Makogon, Y.F. (1997). Hydrates of hydrocarbons. Tulsa, Oklahoma, United States: Pennwell Books, 482 p.

Makogon, Y.F. (2010a). Natural gas hydrates - a promising source of energy. Journal of Natural Gas Science and Engineering, 2(1), 49-59. https://doi. org/10.1016/j.jngse.2009.12.004

Makogon, Yu.F. (2010b). Gazogidraty. Istoriya izucheniya i perspektivy osvoeniya [Gas hydrates. History of study and perspective of development]. Geology and Minerals of the World Ocean, (2), 5-21 (in Russian).

Maksymova, E. (2018). Selecting the method of gas hydrate deposits development in terms of the regularities of their formation. Mining of Mineral Deposits, 12(1), 103-108. https://doi.org/10.15407/ mining 12.01.103

Maksymova, E., \& Kostrytska, S. (2018). Geological and structural prerequisites of gas-bearing capacity and gas hydrate formation in the World Ocean (in terms of the Black Sea). Journal of Geology, Geography and Geoecology, 27(2), 294-304. https:// doi.org/10.15421/111853

Nikishin, A.M., Okay, A.I., Tüysüz, O., Demirer, A., Amelin, N., \& Petrov, E. (2015). The Black Sea basins structure and history: new model based on new deep penetration regional seismic data. Part 1: basins structure and fill. Marine and Petroleum Geology, (59), 638-655. https://doi.org/10.1016/j. marpetgeo.2014.08.017

Pedchenko, M., \& Pedchenko, L. (2017). Analysis of gas hydrate deposits development by applying ele- ments of hydraulic borehole mining technology. Mining of Mineral Deposits, 11(2), 52-58. https:// doi.org/10.15407/mining11.02.052

Petlovanyi, M. (2016). Influence of configuration chambers on the formation of stress in multi-modulus mass. Mining of Mineral Deposits, 10(2), 48-54. https://doi.org/10.15407/mining10.02.048

Petlovanyi, M., Lozynskyi, V., Zubko, S., Saik, P., \& Sai, K. (2019). The influence of geology and ore deposit occurrence conditions on dilution indicators of extracted reserves. Rudarsko Geolosko Naftni Zbornik, 34(1), 83-91. https://doi.org/10.17794/ rgn.2019.1.8

Petlovanyi, M.V., \& Medianyk, V.Y. (2018). Assessment of coal mine waste dumps development priority. Naukovyi Visnyk Natsionalnoho Hirnychoho Universytetu, (4), 28-35. https://doi.org/10.29202/ nvngu/2018-4/3

Petlovanyi, M.V., Lozynskyi, V.H., Saik, P.B., \& Sai, K.S. (2018). Modern experience of low-coal seams underground mining in Ukraine. International Journal of Mining Science and Technology, 28(6), 917923. https://doi.org/10.1016/j.ijmst.2018.05.014

Piwniak, G., Bondarenko, V., Salli, V., Pavlenko, I., \& Dychkovskiy, R. (2007). Limits to economic viability of extraction of thin coal seams in Ukraine. Technical, Technological and Economical Aspects of Thin-Seams Coal Mining, International Mining Forum, 129-132. https://doi.org/10.1201/ noe0415436700.ch16

Processes for methane production from gas hydrates. (2010). Green Energy and Technology, 161-181. https://doi.org/10.1007/978-1-84882-872-8 5

Rogers, R. (2015). Producing methane from offshore hydrates. Offshore Gas Hydrates, 101-133. https:// doi.org/10.1016/b978-0-12-802319-8.00004-8

Shnyukov, E.F. (2013). Mud volcanoes of the Black Sea as a prospecting indicator of methane gas hydrates. Lithology and Mineral Resources, 48(2), 114121. https://doi.org/10.1134/s0024490213010045

Starostenko, V.I., Shnyukov, E.F., Kobolev, V.P., Rusakov, O.M., \& Kutas, R.I., (2008). Degassing of the Northern Black Sea - gas seepage and mud volcanism. Caspian and Black Sea Geosciences Conference. $\quad$ https://doi.org/10.3997/2214$\underline{4609.20146103}$

Thakur, N.K., \& Rajput, S. (2010). Gas Hydrates. Exploration of Gas Hydrates, 49-72. https://doi. org/10.1007/978-3-642-14234-5 3

Trofimuk, A.A., Cherskiy, N.V., Makagon, Y.F., \& Tsarev, V.P. (1973). Possible mechanism of the accumulation of natural gas. International $\mathrm{Ge}$ ology Review, 15(9), 1042-1046. https://doi. org/10.1080/00206817309475983

Vespremeanu, E., \& Golumbeanu, M. (2017). Geophysics of the Black Sea basin. The Black Sea, 27-47. https://doi.org/10.1007/978-3-319-70855-3_4

Zakon Ukrainy "Pro naftu $i$ has" [Law of Ukraine "About oil and gas"]. (2018). Kyiv, Ukraine: Verkhovna Rada of Ukraine (in Ukrainian). 